\title{
Prognostic of the New Nests of Seropositive Mothers Beneficiaries of the Prevention of Mother-Child Transmission in the City of Mbuji-Mayi/Drc
}

\author{
Jean Christophe Bukasa Tshilonda ${ }^{{ }^{*}}$, Ivon Kasonga ${ }^{1}$, Isaac Kalenda Ilunga ${ }^{1}$, \\ Moise Kanyiki Katala', Justin Tshibangu Kandala', Valentin Kabambi Bukasa1, \\ Ennock Mbuyi Kabeya', Nana Dikoma Misenga1, Thérèse Kapenga Mitanta2, \\ Bertin Mpaka Mpaka², Mediatrice Kasheta Mabondo², Olivier Ejiba Nyongonyi2, \\ Paulin Kabamba Lupueka², Alain Ngoyi Kibambe², Alexis Ntambwe Mayombo3, \\ Emmanuel Mubala Mpetemba ${ }^{4}$, Michel Kabamba Nzaji ${ }^{5}$
}

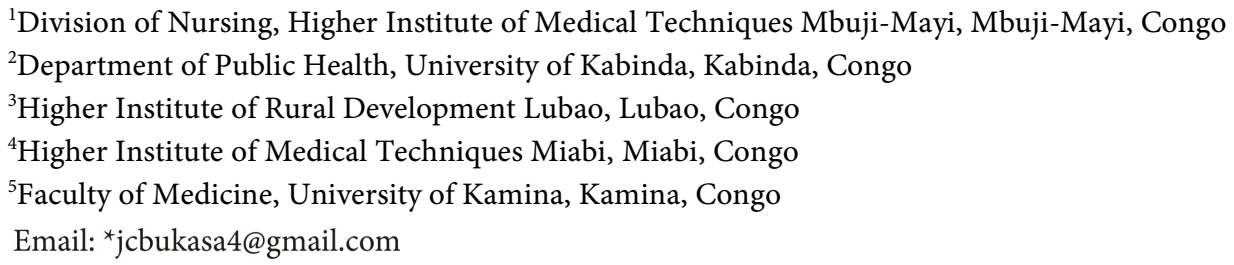

How to cite this paper: Bukasa Tshilonda, J.C., Kasonga, I., Kalenda Ilunga, I., Kanyiki Katala, M., Tshibangu Kandala, J., Kabambi Bukasa, V., Mbuyi Kabeya, E., Dikoma Misenga, N., Kapenga Mitanta, T., Mpaka Mpaka, B., Kasheta Mabondo, M., Ejiba Nyongonyi, O., Kabamba Lupueka, P., Ngoyi Kibambe, A., Ntambwe Mayombo, A., Mubala Mpetemba, E. and Kabamba Nzaji, M. (2019) Prognostic of the New Nests of Seropositive Mothers Beneficiaries of the Prevention of Mother-Child Transmission in the City of Mbuji-Mayi/Drc. Open Access Library Journal, 6: e5267. https://doi.org/10.4236/oalib.1105267

Received: February 20, 2019

Accepted: April 25, 2019

Published: April 28, 2019

\begin{abstract}
Objective: The objective of this study is to evaluate the success of Mother-to-Child Transmission Prevention (PMTCT) is reducing the morbidity and mortality of newborns related to HIV/AIDS. Materials and Methods: This is a descriptive correlational study whose data collection is done in a transversal way from 01 to 30 June 2017 among HIV-positive women screened and we antiretroviral treatment in the health area targeted by this study. To collect this data, we used the semi-structured technical interview face-to-face using a questionnaire. Results. The results of the bivariate analysis revealed the HIV positive outcome in newborns of HIV-positive mothers is significantly related to the following factors (i.e,. $\mathrm{p}<0.05$ ): the parity of more than 5 children; lack of knowledge of some HIV infection pathways; lack of knowledge of some factors that promote the transmission of HIV from mother to child, such as: several infections in the mother; mixed feeding; lack of treatment of the mother; multiple pregnancies; non-monitoring of PMTCT activities; childbirth at home; mixed feeding and non-monitoring of PMTCT services with all pregnancies after-positive HIV diagnosis; lack of knowledge of the center offering the PMTCT service in
\end{abstract}


Copyright ( 2019 by author(s) and Open Access Library Inc.

This work is licensed under the Creative Commons Attribution International License (CC BY 4.0).

http://creativecommons.org/licenses/by/4.0/ service within its radius; poor monitoring of antiretroviral therapy and the effect of not HAVING applied to family planning method. Conclusion: The WHO advises inside this box to promote education, information and communication services for health that are ignored by the population using the available communication channels in the respective areas; apply mass communication to inform pregnant women about the existence of PMTCT services in health centers or hospitals.

\section{Subject Areas}

Gynecology \& Obstetrics, HIV, Public Health

\section{Keywords}

Prognosis, Newborns, HIV-Positive Mothers, PMTCT

\section{Introduction}

While encouraging progress has been observed in countries where the disease burden is high and in low- and middle-income, efforts are deployed in the mother-child transmission of HIV worldwide, [1].

The mother-child transmission in the absence of prevention is estimated at $40 \%$ of children born to HIV-infected mothers who are infected. Among them, an estimated two-thirds are infected during pregnancy and childbirth, a third during breastfeeding [2].

In the world, 17.5 million women are infected with HIV/AIDS and every year, about 1.4 million women living with HIV in low- and middle-income countries become pregnant (8.0\%), and about 2.3 million children under 15 are infected [3]. The same source indicates that more than $90 \%$ of infections in infants and young children are due to mother to child transmission, either during pregnan$c y$, labor and delivery, or during breastfeeding. If nothing is done, almost one in three children born to mothers with HIV will be infected himself (in Europe for example, new HIV infections in children are estimated at 190,000 of which 15,000 are from Ukraine, the countries occupying the first place in the European continent).

In Africa, the situation analysis and response to the AIDS epidemic in 2006 reveals that $30 \%$ of children born to HIV-positive mothers are infected (the distribution of the frequency of pregnancies and children infected is different from one country to another), and countries pay heavily are: South Africa, Zimbabwe $45 \% 41 \%$ [4].

In the Democratic Republic of Congo, DRC, the joint report of the national program against STI/AIDS and WHO reported $20.5 \%$ seroconversion in children born of HIV positive mothers HIV [5]. This area is less exploited by researchers in the DRC.

Also in Kasai Oriental, particularly in the city of Mbuji-Mayi, the results pre- 
sented by the provincial coordinating fight against STI/AIDS reveal that in 2014, among children followed, 15 samples were taken of which 4 children were HIV $+26.6 \%$, while in 2015,10 of 115 children positive sample is $8.7 \%$ while in 2016 , 92 samples taken among which 7 are positive 7.6\% [6].

So to prevent mother to child transmission of HIV, the PMTCT program was considered an access response to antiretroviral (ARV) having the best cost/efficiency and one of the most relevant approaches to preventing HIV infection in children [7].

Our objective is to evaluate the impact of PMTCT into health zones having in their interventions; the prevention of HIV transmission from mother to child finally helps the program to adjust prevention and achieve the goal 4 and 5 of the millennium "reduce maternal and child mortality related to HIV/AIDS 90\%".

\section{Material and Method}

This is a descriptive correlational study in which data collection is done in a transversal way of 1 to 30 June 2017 among screened women with HIV and on antiretroviral treatment in the targeted area health study. To get to collect these data, we used the technique of semi interview-structured face to face with a questionnaire.

\section{Results}

\subsection{Presentation of the Results}

It appears from this Table 1 that $52.0 \%$ of respondents had positive women age over 30 years, $73.1 \%$ were married which $55.7 \%$ was polygamous, $36.0 \%$ had a secondary level of study, $921 \%$ were Christian, $55.4 \%$ had less than 5 children.

After analysis of these results (Table 2), we find that $94.2 \%$ of respondents knew about the modes of transmission of HIV/AIDS, compared to the knowledge of practices favoring transmission from mother to child, $21.5 \%$ had mentioned multiple maternal infections, $18.6 \%$ spoke of mixed feeding; $77.8 \mathrm{M}$ evoked the absence of maternal treatment, $80.8 \%$ spoke of multiple pregnancies and $82.3 \%$ spoke of sexual multistakeholder. In connection with the knowledge of practices to prevent transmission from mother to child $97.2 \%$ evoked voluntary testing for HIV, 94.2\% evoked monitoring PMTCT program, $88.5 \%$ had also spoken to the non-delivery home, $79.3 \%$ spoke of avoidance of mixed feeding, $83.6 \%$ of them were applicable all three proposals given above. 95

Regarding the results of this Table 3 and Table 4, 94.2\% of respondents knew the center offering PMTCT services within its range, $43.3 \%$ was embarrassed to go to the NPC, $93.2 \%$ felt that there were privacy in service, $95.7 \%$ received regular ARVs, $87.6 \%$ was regularly the contrimozasole and $90.4 \%$ had received a proposal for contraception.

Compared to this Table 5, 69.3\% of respondents were engaged in a professional activity. Regarding the knowledge of sexual practices at risk of contamina- 
tion, $97.4 \%$ spoke of unprotected sexual practice, $21.6 \%$ also spoke of homosexuality and $94.9 \%$ spoke of early sexual intercourse. In connection with the practical knowledge to avoid contamination of the child, $77.4 \%$ had spoken mother of voluntary testing and $67.2 \%$ evoked mixed feeding; $87.0 \%$ were prepared to implement a family planning method and $64.0 \%$ had no income generating activity.

\subsection{Results of Bivariate Analyzes}

It appears from this Table 6 that the parity of more than 5 children $(\mathrm{X} 2=10.05$; $\mathrm{p}=0.001)$ was the only factor that was the basis of HIV status of children born to HIV positive mothers.

After analysis of these results (Table 7) should be said that ignorance of certain HIV modes of transmission (X2 $=70.06 ; \mathrm{p}=0.000$ ), lack of knowledge: several maternal infections $(\mathrm{X} 2=91.16, \mathrm{p}=0.000)$, mixed feed $(\mathrm{X} 2=76.5 ; \mathrm{p}=$ $0.000)$, the absence of treatment of the mother $(\mathrm{X} 2=74.17 ; \mathrm{p}=0.000)$, multiple pregnancies $(\mathrm{X} 2=85.98 ; \mathrm{p}=0.000)$ and multiple sex partners as factors promoting HIV transmission from mother to child. What are factors that are associated with the child's infection from HIV-positive mothers.

These results also show that the lack of knowledge of PMTCT $(\mathrm{X} 2=7.00, \mathrm{p}=$ $0.008)$, home delivery $(\mathrm{X} 2=44.57, \mathrm{p}=0.000)$, avoid mixed feeding $(\mathrm{X} 2=70.06$, $\mathrm{p}=0.000)$ as a practice to prevent mother-to-child HIV transmission and non-follow-up of PMTCT service with all pregnancies after positive HIV diagnosis $(\mathrm{X} 2=68.01, \mathrm{p}=0.000)$. What are some of the factors that are associated with the contamination of the child from HIV-positive mothers?

Given these results (Table 8), the conclusion is that it is links of association between HIV seropositivity among children born to HIV positive mothers and the center of ignorance offering PMTCT services in its radius $(\mathrm{X} 2=10.82 ; \mathrm{p}=$ $0.001)$, poor monitoring of antiretroviral treatment $(\mathrm{X} 2=18.88 ; \mathrm{p}=0.000)$, the absence of contrimoxazole by time $(\mathrm{X} 2=12.62 ; \mathrm{p}=0.000)$ and the effect of not implementing a FP method $(\mathrm{X} 2=17.36 ; \mathrm{p}=0.000)$.

After analysis of these results (Table 9) consistent that certain characteristics influence the HIV status of HIV children born to HIV positive mothers, they are: ignorance of sexual violence (X2 $=16.11 ; \mathrm{p}=0.000)$, ignorance of the early sex before the age of majority (X2 $=5.46 ; \mathrm{p}=0.019)$ as sexual risk of HIV infection/AIDS from mother to child and ignorance of mixed feeding as a way to avoid contamination from mother to child.

\section{Discussion}

The risk of transmission from mother-to-child is a permanent concern faced by health professionals and all partners involved in the fight against HIV/AIDS. Due to the possibility of vertical contamination and therefore void the dream of an HIV/AIDS. The contamination of the transmission of mother-to-child has been documented in several countries. 
Table 1. Distribution of subjects by socio-demographic categories.

\begin{tabular}{|c|c|c|}
\hline Characteristics & Employees $(n=469)$ & Percentage \\
\hline \multicolumn{3}{|l|}{ Age } \\
\hline$\leq 30$ years & 244 & 52.0 \\
\hline$\geq 31$ years & 225 & 48.0 \\
\hline \multicolumn{3}{|l|}{ Civil status } \\
\hline Married & 343 & 73.1 \\
\hline Unmarried & 126 & 26.9 \\
\hline \multicolumn{3}{|l|}{ Marital status } \\
\hline Monogamous & 207 & 44.1 \\
\hline Polygamous & 262 & 55.9 \\
\hline \multicolumn{3}{|l|}{ Level of education } \\
\hline Primary & 142 & 30.2 \\
\hline Secondary & 169 & 36.0 \\
\hline University & 56 & 11.9 \\
\hline Without level & 102 & 21.7 \\
\hline \multicolumn{3}{|l|}{ Religion } \\
\hline Christian & 432 & 92.1 \\
\hline Muslim & 37 & 7.9 \\
\hline \multicolumn{3}{|l|}{ Parity } \\
\hline 1 to 5 children & 260 & 55.4 \\
\hline 6 and children & 209 & 44.6 \\
\hline \multicolumn{3}{|c|}{ Have a professional occupation } \\
\hline Yes & 323 & 68.9 \\
\hline No & 145 & 31.1 \\
\hline
\end{tabular}

Table 2. Distribution of subjects according to their knowledge about the mode of transmission of HIV and practices favoring contamination HIV.

\begin{tabular}{cccc}
\hline Characteristics & Category & Effective & $\%$ \\
\hline $\begin{array}{c}\text { Mode of knowledge } \\
\text { of HIV contamination }\end{array}$ & Yes & 442 & 94.2 \\
Number of pregnancies where & No & 27 & 5.8 \\
the PMTCT service was followed & All pregnancies & 447 & 95.3 \\
$\begin{array}{c}\text { Knowledge practices that promote } \\
\text { the transmission of mother to child }\end{array}$ & some & 22 & 4.7 \\
Several maternal infections & Yes & 101 & \\
Mixed feeding & No & 368 & 78.5 \\
& Yes & 87 & 18.6 \\
& No & 382 & 81.4 \\
\hline
\end{tabular}




\section{Continued}

\begin{tabular}{|c|c|c|c|}
\hline \multirow[t]{2}{*}{ No treatment of the mother } & Yes & 365 & 77.8 \\
\hline & No & 104 & 22.2 \\
\hline \multirow[t]{2}{*}{ Multiple pregnancies } & Yes & 379 & 80.8 \\
\hline & No & 90 & 19.2 \\
\hline \multirow[t]{2}{*}{ Having multiple partners } & Yes & 386 & 82.3 \\
\hline & No & 83 & 17.7 \\
\hline \multicolumn{4}{|l|}{$\begin{array}{l}\text { Knowledge of practices to prevent } \\
\text { transmission from mother to child }\end{array}$} \\
\hline \multirow[t]{2}{*}{ Getting tested CS } & Yes & 456 & 97.2 \\
\hline & No & 13 & 2.8 \\
\hline \multirow[t]{2}{*}{ Follow the PMTCT program } & Yes & 442 & 94.2 \\
\hline & No & 27 & 5.8 \\
\hline \multirow[t]{2}{*}{ Is not birth at home } & Yes & 415 & 88.5 \\
\hline & No & 54 & 11.5 \\
\hline \multirow[t]{2}{*}{ Avoid mixed feeding } & Yes & 372 & 79.3 \\
\hline & No & 97 & 20.7 \\
\hline \multirow[t]{2}{*}{ All options are applied } & Yes & 392 & 83.6 \\
\hline & No & 77 & 16.4 \\
\hline \multirow[t]{2}{*}{ No options are applied } & Yes & 47 & 10.0 \\
\hline & No & 422 & 90.0 \\
\hline \multicolumn{4}{|l|}{ Attitude to pregnancy } \\
\hline \multirow[t]{2}{*}{ Refer to CS with the PMTCT service } & Yes & 413 & 88.1 \\
\hline & No & 56 & 11.9 \\
\hline \multirow[t]{2}{*}{ Follow the treatment at home } & Yes & 351 & 74.8 \\
\hline & No & 118 & 25.2 \\
\hline \multirow[t]{2}{*}{ Both options are made } & Yes & 365 & 77.8 \\
\hline & No & 104 & 22.2 \\
\hline \multirow[t]{2}{*}{ No options are made } & Yes & 354 & 75.5 \\
\hline & No & 115 & 24.5 \\
\hline
\end{tabular}

Table 3. HIV prevalence among children of HIV positive mothers.

\begin{tabular}{ccc}
\hline HIV status of children born HIV-positive mother & Effective & Percentage \\
\hline Negative & 419 & 89.3 \\
Positive & 50 & 10.7 \\
\hline
\end{tabular}

The prevalence was $10.7 \%$. 
Table 4. Distribution of subjects by organizational factors.

\begin{tabular}{cccc}
\hline Characteristics & Categories & $\begin{array}{c}\text { Employees } \\
(\mathbf{n}=469)\end{array}$ & Percentage \\
\hline $\begin{array}{c}\text { Knowledge center offering } \\
\text { PMTCT services within its range }\end{array}$ & Yes & 442 & 94.2 \\
Have the embarrassment of going to the CPN & No & 27 & 5.8 \\
Yes & 203 & 43.3 \\
Guaranteed confidentiality in service & No & 266 & 56.7 \\
Have ARVs regularly & Yes & 437 & 93.2 \\
& No & 32 & 6.8 \\
Have cotrimoxazole regularly in clinic & Yes & 449 & 95.7 \\
& No & 20 & 4.3 \\
Receiving a proportion of family planning method & Yes & 411 & 87.6 \\
& No & 424 & 12.4 \\
& & 58 & 90.4 \\
\hline
\end{tabular}

Table 5. Distribution of cases socio-professional characteristics.

\begin{tabular}{|c|c|c|c|}
\hline Characteristics & Categories & $\begin{array}{l}\text { Employees } \\
(\mathrm{n}=469)\end{array}$ & $\%$ \\
\hline \multicolumn{4}{|l|}{ Knowledge of sexual practices contamination } \\
\hline \multirow[t]{2}{*}{ Unprotected sexual practice } & Yes & 457 & 97.4 \\
\hline & No & 12 & 2.6 \\
\hline \multirow[t]{2}{*}{ Homosexuality } & Yes & 10 & 2.1 \\
\hline & No & 459 & 97.9 \\
\hline \multirow[t]{2}{*}{ Sexual violence } & Yes & 462 & 98.5 \\
\hline & No & 7 & 1.5 \\
\hline \multirow[t]{2}{*}{ Early sex before age eater } & Yes & 445 & 94.9 \\
\hline & No & 24 & 5.1 \\
\hline \multicolumn{4}{|l|}{$\begin{array}{l}\text { Knowledge of practices to avoid } \\
\text { contamination of the child }\end{array}$} \\
\hline \multirow[t]{2}{*}{ Screening the mother } & Yes & 363 & 77.4 \\
\hline & No & 106 & 22.6 \\
\hline \multirow[t]{2}{*}{ Treatment of the mother and child } & Yes & 359 & 76.5 \\
\hline & No & 110 & 23.5 \\
\hline \multirow[t]{2}{*}{ Mixed feeding } & Yes & 315 & 67.2 \\
\hline & No & 154 & 32.8 \\
\hline \multirow[t]{2}{*}{ Be near to apply the methods of family planning } & Yes & 408 & 87.0 \\
\hline & No & 61 & 13.0 \\
\hline \multirow[t]{2}{*}{ Have an income generating activity } & Yes & 169 & 36.0 \\
\hline & No & 300 & 64.0 \\
\hline
\end{tabular}


Table 6. Association between socio-demographic categories of HIV-positive mothers and become the child of these mothers.

\begin{tabular}{|c|c|c|c|c|c|}
\hline \multirow{2}{*}{ Characteristics } & \multicolumn{2}{|c|}{ Become of the child } & \multirow{2}{*}{ GOLD } & \multirow{2}{*}{$\mathbf{P}$} & \multirow{2}{*}{$S$} \\
\hline & Positive & Negative & & & \\
\hline \multicolumn{6}{|l|}{ Age } \\
\hline$\leq 30$ years & 22 & 222 & 0.70 & 0.23 & NS \\
\hline$\geq 31$ years & 28 & 197 & & & \\
\hline \multicolumn{6}{|l|}{ Civil status } \\
\hline Married & 40 & 303 & 1.34 & 0.246 & NS \\
\hline Unmarried & 10 & 116 & & & \\
\hline \multicolumn{6}{|l|}{ Marital status } \\
\hline Monogamous & 34 & 228 & 3.34 & 0.067 & NS \\
\hline Polygamous & 16 & 191 & & & \\
\hline \multicolumn{6}{|l|}{ Level of education } \\
\hline Without primary level and & 24 & 220 & 0.36 & 0.546 & NS \\
\hline Secondary and university & 26 & 199 & & & \\
\hline \multicolumn{6}{|l|}{ Religion } \\
\hline Christian & 46 & 386 & 0.00 & 0.975 & NS \\
\hline Muslim and pagan & 4 & 33 & & & \\
\hline \multicolumn{6}{|l|}{ Parity } \\
\hline 1 to 5 children & 26 & 183 & 10.05 & 0.001 & $S$ \\
\hline 6 more children & 24 & 236 & & & \\
\hline
\end{tabular}

Table 7. Association between knowledge of HIV transmission mode, practice promoting HIV contamination and become the child of these mothers.

\begin{tabular}{|c|c|c|c|c|c|}
\hline \multirow{2}{*}{ Characteristics } & \multicolumn{2}{|c|}{ Become of the child } & \multirow{2}{*}{$\mathrm{X} 2$} & \multirow{2}{*}{$\mathbf{P}$} & \multirow{2}{*}{$\mathrm{S}$} \\
\hline & Negative & Positive & & & \\
\hline \multicolumn{6}{|c|}{$\begin{array}{l}\text { Correct knowledge of HIV } \\
\text { contamination modes }\end{array}$} \\
\hline No & 64 & 33 & 70.06 & $<0.001$ & $\mathrm{~S}$ \\
\hline Yes & 355 & 17 & & & \\
\hline \multicolumn{6}{|c|}{$\begin{array}{l}\text { Knowledge practices that promote } \\
\text { the transmission of mother to child }\end{array}$} \\
\hline \multicolumn{6}{|c|}{ Several maternal infections } \\
\hline Yes & 355 & 13 & 91.16 & $<0.001$ & $\mathrm{~s}$ \\
\hline No & 64 & 37 & & & \\
\hline \multicolumn{6}{|l|}{ Mixed feeding } \\
\hline Yes & 364 & 18 & 76.5 & $<0.001$ & $\mathrm{~s}$ \\
\hline No & 55 & 32 & & & \\
\hline
\end{tabular}




\section{Continued}

Without treatment

of the mother and child

$$
\begin{aligned}
& \text { Yes } \\
& \text { No }
\end{aligned}
$$

69

$$
15
$$

74.17

$<0.001$

S

Multiple pregnancies

$$
\begin{aligned}
& \text { Yes } \\
& \text { No }
\end{aligned}
$$

Having multiple partners

$$
\begin{aligned}
& \text { Yes } \\
& \text { No }
\end{aligned}
$$

Knowledge of practices to prevent transmission from mother to child

Getting tested CS

$$
\text { Yes }
$$

Follow the PMTCT program

Yes
No

$$
\begin{aligned}
& \text { Yes } \\
& \text { No }
\end{aligned}
$$

Avoid mixed feeding

$$
\text { Yes }
$$

Attitude to pregnancy

\section{Refer to CS with the PMTCT service}

$$
\begin{aligned}
& \text { Yes } \\
& \text { No }
\end{aligned}
$$

Follow the treatment at home

$$
\text { Yes }
$$$$
\text { No }
$$

No options are made

$$
\text { Yes }
$$$$
\text { No }
$$

Number of pregnancies where the PMTCT service was followed

$\begin{array}{ll}321 & 33 \\ 98 & 17\end{array}$


Table 8. Association between certain organizational characteristics and become the child of these mothers.

\begin{tabular}{|c|c|c|c|c|c|}
\hline \multirow{2}{*}{ Characteristics } & \multicolumn{2}{|c|}{ Become of the child } & \multirow{2}{*}{$\mathrm{X} 2$} & \multirow{2}{*}{$\mathrm{p}$} & \multirow{2}{*}{$S$} \\
\hline & Negative & Positive & & & \\
\hline \multicolumn{6}{|c|}{ Knowledge center offering } \\
\hline \multicolumn{6}{|c|}{ PMTCT services within its range } \\
\hline Yes & 400 & 42 & 10.82 & 0.001 & $s$ \\
\hline No & 19 & 8 & & & \\
\hline \multicolumn{6}{|c|}{$\begin{array}{l}\text { Have the embarrassment } \\
\text { of going to the CPN }\end{array}$} \\
\hline Yes & 176 & 27 & 2.61 & 0.105 & NS \\
\hline No & 243 & 23 & & & \\
\hline \multicolumn{6}{|c|}{ Guaranteed confidentiality in service } \\
\hline Yes & 390 & 47 & 0.05 & 0.807 & NS \\
\hline No & 29 & 3 & & & \\
\hline \multicolumn{6}{|c|}{ Proper monitoring of ARV treatment } \\
\hline Yes & 407 & 42 & 18.88 & $<0.001$ & $S$ \\
\hline No & 12 & 8 & & & \\
\hline \multicolumn{6}{|c|}{ Have cotrimoxazole regularly in clinic } \\
\hline Yes & 375 & 36 & 12.62 & $<0.001$ & $s$ \\
\hline No & 44 & 14 & & & \\
\hline \multicolumn{6}{|c|}{$\begin{array}{l}\text { Receiving a proportion of } \\
\text { family planning method }\end{array}$} \\
\hline Yes & 387 & 37 & 17.36 & $<0.001$ & $S$ \\
\hline No & 32 & 13 & & & \\
\hline
\end{tabular}

Table 9. Association between certain socio-professional characteristics and become the child of these mothers.

\begin{tabular}{|c|c|c|c|c|c|}
\hline \multirow{2}{*}{ Characteristics } & \multicolumn{2}{|c|}{ Become of the child } & \multirow{2}{*}{$\mathrm{X} 2$} & \multirow{2}{*}{$\mathrm{p}$} & \multirow{2}{*}{$\mathbf{S}$} \\
\hline & Negative & Positive & & & \\
\hline \multicolumn{6}{|c|}{ Have a professional occupation } \\
\hline Yes & 294 & 31 & 1.40 & 0.236 & NS \\
\hline No & 125 & 19 & & & \\
\hline \multicolumn{6}{|c|}{$\begin{array}{l}\text { Knowledge of sexual } \\
\text { practices contamination }\end{array}$} \\
\hline \multicolumn{6}{|c|}{ Unprotected sexual practice } \\
\hline Yes & 409 & 48 & 0.46 & 0.494 & NS \\
\hline No & 10 & 2 & & & \\
\hline \multicolumn{6}{|l|}{ Sexual violence } \\
\hline Yes & 416 & 46 & 16.11 & $<0.001$ & $\mathrm{~S}$ \\
\hline No & 3 & 4 & & & \\
\hline
\end{tabular}




\section{Continued}

Early sex before age eater

$\begin{array}{lccccc}\text { Yes } & 401 & 44 & 5.46 & 0.019 & \text { S } \\ \text { No } & 18 & 6 & & & \end{array}$

Knowledge of practices to avoid contamination of the child

Maternal screening lack

Yes

No

Lack of treatment of the mother and child

Yes

No

Mixed feeding

Yes

No

Be near to apply the

methods of family planning

Yes

No

Have an income generating activity

\begin{tabular}{llllll} 
Yes & 142 & 27 & 7.83 & 0.005 & S \\
No & 277 & 23 & & & \\
\hline
\end{tabular}

326

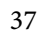

0.36

0.543

NS

93

13

326

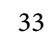

3.46

0.062

NS

$93 \quad 17$

302

13

43.00

$<0.001$

S

$117 \quad 37$

2.41

0.119

NS

$51 \quad 10$

Yes 
sence of preventive treatment, approximately $25 \%$ - $40 \%$ of children are infected with 5\% - 10\% during pregnancy, 15\% during labor and about 5\% - 15\% through breastfeeding. By 1994, the PACTG 076-ANRS 024 study demonstrated the remarkable efficacy of AZT to reduce mother to child transmission of HIV by $26 \%$ to $8 \%$ in women not breastfeeding their children. To test the effectiveness of anti-retroviral drugs in the mother and/or child to reduce transmission during breastfeeding [12] [13].

Many factors have been studied in the hope of preventing mother-child transmission of HIV/AIDS. The correction of these factors is unfortunately not always associated with a reduction in transmission. The risk of transmission during pregnancy and childbirth is higher when the mother is at an advanced stage of the disease, their immune system is already impaired or it has a micronutrient deficiency such as vitamin A [13].

However it is the association between viral load and transmission, which is the most significant: the higher the viral load, the higher the risk of transmission is high. Some evidence suggests that transmission is more common with certain subtypes of HIV-1 as subtype C, particularly widespread in East Africa, but these results were not confirmed (16). Due to its rapid mutational capabilities, HIV gradually adapts better to escape the natural or artificial defenses (ART) host: thus, the absence of agreement between the mother and child for certain characteristics HLA would be protective for children [14].

The results of this study show that the HIV status of children born to HIV positive mothers is influenced by the following factors: parity of more than 5 children $(\mathrm{X} 2=10.05 ; \mathrm{p}=0.001)$, the ignorance of certain HIV modes of transmission $(\mathrm{X} 2=70.06 ; \mathrm{p}=0.000)$, the ignorance of certain factors favoring transmission of HIV from mother to child as: several maternal infections (X2 = 91.16; $\mathrm{p}=0.000)$, mixed feed $(\mathrm{X} 2=76.5 ; \mathrm{p}=0.000)$, the absence of treatment of the mother $(\mathrm{X} 2=74.17 ; \mathrm{p}=0.000)$, multiple pregnancies $(\mathrm{X} 2=85.98 ; \mathrm{p}=0.000)$; Besides these factors, the results also show that ignorance of certain practices to prevent transmission of HIV from mother to child as: failure monitoring PMTCT (X2 = 7.00; $\mathrm{p}=0.008)$, home delivery (X2 = 44.57; $\mathrm{p}=0.000)$, mixed feeding $(\mathrm{X} 2=70.06 ; \mathrm{p}=0.000)$ and not follow the PMTCT service with all the pregnancy after a positive HIV diagnosis $(\mathrm{X} 2=68.01 ; \mathrm{p}=0.000)$;

The same study also revealed that the center of ignorance offering PMTCT services in its radius $(\mathrm{X} 2=10.82 ; \mathrm{p}=0.001)$, poor monitoring of antiretroviral treatment $(\mathrm{X} 2=18.88 ; \mathrm{p}=0.000)$, the absence of contrimoxazol by time $(\mathrm{X} 2=$ $12.62 ; \mathrm{p}=0.000)$ and the effect of not implementing a method of family plan$\operatorname{ning}(\mathrm{X} 2=17.36 ; \mathrm{p}=0.000)$;

The other factors identified in this study are: ignorance of sexual violence (X2 $=16.11 ; \mathrm{p}=0.000)$, ignorance of early sex before the age of majority (X2 = 5.46; $\mathrm{p}=0.019)$ as sexual risk of HIV infection/AIDS from mother to child and ignorance of mixed feeding as a way to prevent contamination of the mother to her child. 


\section{Conclusion}

The mother-child transmission in the absence of prevention is estimated at $40 \%$ of children born to HIV-positive mothers who are infected. Among them, an estimated two-thirds are infected during pregnancy and childbirth, a third during breastfeeding. Thus the WHO advises in this case to promote education, information and communication to health services that are ignored by the people using the communication channels available in the respective areas; apply the mass communication to inform pregnant women of the existence of PMTCT services at health centers or hospitals.

\section{Conflicts of Interest}

The authors declare no conflicts of interest regarding the publication of this paper.

\section{References}

[1] UN AIDS (2005) Report on HIV/AIDS.

[2] UNAIDS (2013) The Vectors and Mode of Transmission of HIV, France. 145 p.

[3] UN AIDS (2014) Report on the Global AIDS Epidemic, Genesis. 151 p.

[4] Ndagijimana, J.C. (2005) Evaluation of the Impact on the Mother-Child Transmission Program Presentation HIV Case Gabgayi Health Center. UNR, Butare.

[5] WHO (2010) Guidelines for Interventions on HIV/AIDS in Emergency Situations. WHO, Geneva, 111 p.

[6] WHO (2003) Millennium Development Goals for Health: The Way of the Future. WHO, Geneva, 42 p.

[7] National Program of Fight against AIDS (2015) Annual Report of Activities against STI/AIDS. Mbuji-Mayi, 86 p.

[8] Potvin, L. and Gauvin, L. (2000) Research and Transformation of Professional Practices in Health Promotion. Ruptures, revue transdisciplinaire en santé, 7, 57 p.

[9] MOH (2004) Voluntary Screening Board Trainer Guide and Prevention of HIV Transmission from Mother to Child KIGALI.

[10] Beyers, N and Chan, M. (2005) HIV/AIDS Epidemic, Its Impact and Flow of the Tide. The Journal of Medecine and Health Sciences, 19, $57 \mathrm{p}$.

[11] WHO (2015) Global Strategy for Fight against AIDS, Resolution WHA4233. WHO, Geneva, 22 p.

[12] Randriatsarafara, F., et al. (2012) Discriminatory Attitudes Health Professional vis-a-vis the People Living with HIV in Antananarivo in Madagascar, Antananarivo. The Medical Review of Madagascar, $104 \mathrm{p}$.

[13] Kilewo, C., et al. (2000) Counseling and Testing of Pregnant Woman in South-Saharan African: Experience from a Study of Prevention of Mother to Child Transmission in Dares Salaam, Tanzania. French Studies and Research Papers, 17.

[14] UNICEF/WHO (1992) African Family and No. 60 Quarterly Development of Education and Technical Cooperation. UNICEF/WHO, Lomé, Togo, 3. 